\title{
DEVELOPMENTAL VARIATION IN CHROMOSOME BEHAVIOUR
}

\author{
H. REES \\ Agricultural Botony Department, Institute of Rural Science, \\ University College of Woles, Aberystwyth \\ and \\ BERYL NAYLOR
}

$A R C$ Unit of Biometrical Genetics, Genetics Deportment, University of Birminghom

Received 24.xi.59

\section{INTRODUCTION}

Changes which initiate anatomical and physiological differentiation during development also affect chromosomes, whose form and behaviour in consequence may vary between cells of different tissues. A familiar and extreme example is the difference between the chromosomes of the salivary gland cells and those, a hundred times smaller, of nerve ganglion cells in Drosophila larvæ. Differences may sometimes be detected also between component cells within tissues. Thus in the nurse cells of Drosophila ovaries a proportion of cell nuclei are polyploid, the remainder diploid (Hertwig, i935). Chromosome variation therefore provides an additional and useful means for investigating the patterns of cell variation arising during development, especially within tissues where the differences in cell anatomy and physiological activity are otherwise difficult or impossible to detect. In the following account two characters, chiasma frequency and the timing sequence of cell divisions, are investigated at meiosis in the pollen mother cell (p.m.c.) tissue of rye anthers. The aim was, first, to determine whether definite patterns of variation for the characters could be distinguished within the anthers and, second, to inquire into the relations between them.

\section{CHIASMA FREQUENCY}

\section{(i) Method}

To determine the variation along its length each anther was cut transversely into four equal sections-numbered $\mathrm{I}$ to 4 from base to tip. Where metaphases were available in all sections the chiasma frequency was then scored from a sample of cells in each. The plants used were from five inbred, homozygous, lines (see previous papers, e.g. Rees, 1955) and $F_{1}$ hybrids between them.

\section{(ii) The results}

Table I gives the chiasma frequencies per section in one anther from each of $I_{4}$ inbred plants and i2 $F_{1}$ hybrids. The results for each genotype are represented also in fig. I. 
In this graph a definite pattern of variation within the anther is indicated, the chiasma frequency tending to decrease from one end to the other.

A more detailed analysis of the data was desirable and this was achieved by fitting polynomial regressions. In the analysis of variance

TABLE I

Chiasma frequencies per section in rye anthers.

Twenty cells were scored in each section

\begin{tabular}{|c|c|c|c|c|}
\hline \multirow{2}{*}{ Plant } & \multicolumn{4}{|c|}{ Section } \\
\hline & I & 2 & 3 & 4 \\
\hline $\begin{array}{l}P_{I^{1}} \\
P_{I^{2}}{ }^{2}\end{array}$ & $\begin{array}{l}253 \\
239\end{array}$ & $\begin{array}{l}252 \\
24^{8}\end{array}$ & $\begin{array}{l}252 \\
247\end{array}$ & $\begin{array}{l}25 \mathrm{I} \\
250\end{array}$ \\
\hline $\begin{array}{l}P 6^{1} \\
P 6^{2} \\
P 6^{3}\end{array}$ & $\begin{array}{l}239 \\
252 \\
255\end{array}$ & $\begin{array}{l}250 \\
236 \\
257\end{array}$ & $\begin{array}{l}241 \\
246 \\
246\end{array}$ & $\begin{array}{l}244 \\
237 \\
254\end{array}$ \\
\hline $\begin{array}{l}P 7^{1} \\
P 7^{2} \\
P 7^{3}\end{array}$ & $\begin{array}{l}25^{2} \\
244 \\
25^{1}\end{array}$ & $\begin{array}{l}240 \\
244 \\
245\end{array}$ & $\begin{array}{l}23 \text { I } \\
24 \text { I } \\
235\end{array}$ & $\begin{array}{l}249 \\
229 \\
25^{\circ}\end{array}$ \\
\hline $\begin{array}{l}P_{12}{ }^{1} \\
P_{12}{ }^{2} \\
P_{12}{ }^{3}\end{array}$ & $\begin{array}{l}242 \\
252 \\
255\end{array}$ & $\begin{array}{l}247 \\
240 \\
252\end{array}$ & $\begin{array}{l}245 \\
238 \\
237\end{array}$ & $\begin{array}{l}240 \\
240 \\
259\end{array}$ \\
\hline $\begin{array}{l}P_{I} 7^{1} \\
P_{I} 7^{2} \\
P_{I} 7^{3}\end{array}$ & $\begin{array}{l}249 \\
230 \\
247\end{array}$ & $\begin{array}{r}247 \\
246\end{array}$ & $\begin{array}{l}238 \\
244 \\
237\end{array}$ & $\begin{array}{l}242 \\
236 \\
231\end{array}$ \\
\hline $\begin{array}{l}I \times 6^{1} \\
I \times 6^{2} \\
I \times 6^{3} \\
I \times 6^{4} \\
I \times 6^{5} \\
I \times 6^{6}\end{array}$ & $\begin{array}{l}287 \\
285 \\
280 \\
283 \\
285 \\
271\end{array}$ & $\begin{array}{l}282 \\
285 \\
275 \\
277 \\
282 \\
273\end{array}$ & $\begin{array}{l}281 \\
283 \\
278 \\
278 \\
280 \\
275\end{array}$ & $\begin{array}{l}275 \\
281 \\
279 \\
284 \\
278 \\
267\end{array}$ \\
\hline $\begin{array}{l}1 \times 7^{1} \\
1 \times 7^{2} \\
1 \times 7^{3} \\
1 \times 7^{4} \\
1 \times 7^{5} \\
1 \times 7^{6}\end{array}$ & $\begin{array}{l}283 \\
281 \\
286 \\
282 \\
274 \\
276\end{array}$ & $\begin{array}{l}282 \\
282 \\
282 \\
269 \\
280 \\
276\end{array}$ & $\begin{array}{l}282 \\
279 \\
280 \\
273 \\
271 \\
277\end{array}$ & $\begin{array}{l}279 \\
281 \\
277 \\
269 \\
269 \\
277\end{array}$ \\
\hline
\end{tabular}

of the regressions, which is given in table 2, the degrees of freedom for the linear, quadratic and cubic regressions were split into components depending on heterogeneity between genotypes and between plants within genotypes. The conclusions may be summarised as follows :-

I. There is a significant difference between the mean chiasma frequencies of genotypes-due, chiefly, to the heterosis for this character displayed by the $F_{1}$.

2. The significant mean linear regression confirms the gradient in chiasma frequencies from the base to the tip of rye anthers. A relation is clearly established between the chiasma frequency of p.m.c. and their location within the anther. 
3. There is no significant heterogeneity for the linear regression between inbred or outbred genotypes. Within genotypes however it will be observed that the heterogeneity between plants is significantly

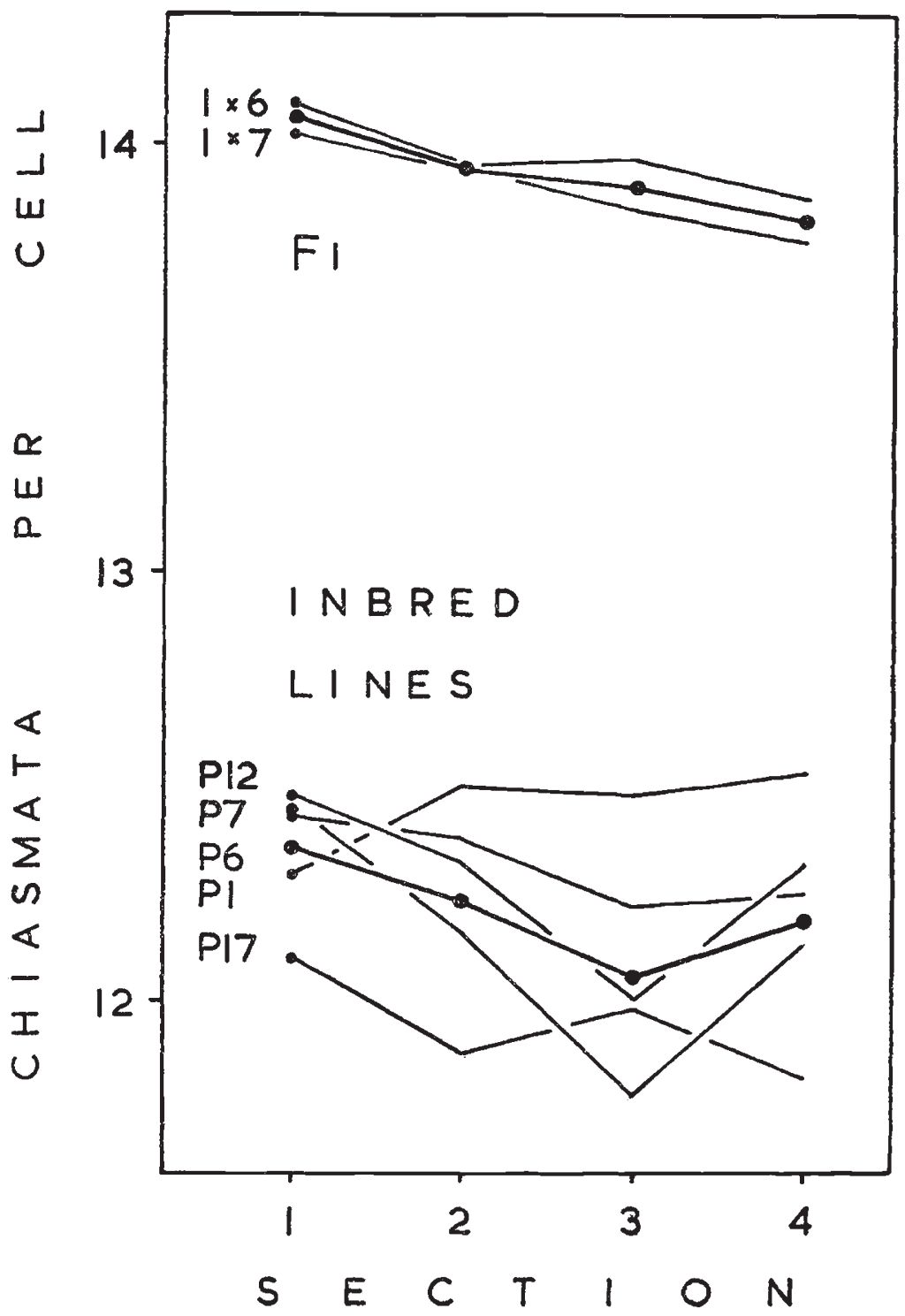

FIG. I.-The distributions of chiasma frequencies in p.m.c. in sections of rye anthers.

larger for inbred than for $F_{1}$ families. Since plants within families are genetically identical it must be concluded that the pattern of developmental variation in the inbred, homozygous, individuals is less uniform, less consistent, than in the heterozygotes (cf. Rees and Thompson, 1956).

4. Neither the mean quadratic nor cubic regressions are significant. 
It would appear however from fig. I, particularly in respect of inbred lines, that there is variation in chiasma frequency distribution that is independent of and additional to that accounted for by the linear regression. Thus section three in anthers of inbred plants tends to have disproportionately low chiasma frequencies.

Further evidence for this additional variation comes from the analysis itself. The mean squares for heterogeneity within inbred and $\mathrm{F}_{1}$ families for both the quadratic and cubic components are significantly

TABLE 2

Polynomial regression analysis of variance--chiasma frequency against anther sections

\begin{tabular}{|c|c|c|c|c|c|c|}
\hline & Item & $\mathrm{N}$ & MS & & VR & $P$ \\
\hline Linear & $\left\{\begin{array}{l}\text { Joint regression } \\
\text { Het. between inbreds and } F_{1} \cdot \\
\text { Het. between inbred genotypes } \\
\text { Het. between } \mathrm{F}_{1} \text { genotypes } \\
\text { Het. within inbred genotypes } \\
\text { Het. within } \mathrm{F}_{1} \text { genotypes }\end{array}\right.$ & \begin{tabular}{c|} 
I \\
I \\
4 \\
I \\
9 \\
IO
\end{tabular} & $\left.\begin{array}{r}264 \cdot 69 \\
0 \cdot 47 \\
23 \cdot 46 \\
1 \cdot 50 \\
45 \cdot 74 \\
\mathrm{I} \cdot 60\end{array}\right\}$ & $24 \cdot 94$ & $10 \cdot 6 \mathrm{I}$ & $0.001-0.01$ \\
\hline Quadratic & $\left\{\begin{array}{l}\text { Joint regression } \\
\text { Het. between inbreds and } \mathrm{F}_{1} \cdot \\
\text { Het. between inbred genotypes } \\
\text { Het. between } \mathrm{F}_{1} \text { genotypes } \\
\text { Het. within inbred genotypes. } \\
\text { Het. within } \mathrm{F}_{1} \text { genotypes }\end{array}\right.$ & $\begin{array}{c}\text { I } \\
\text { I } \\
4 \\
\text { I } \\
9 \\
\text { IO }\end{array}$ & $\left.\begin{array}{r}60 \cdot 01 \\
33 \cdot 5^{8} \\
27 \cdot 90 \\
0 \cdot 5^{2} \\
51 \cdot 09 \\
10 \cdot 77\end{array}\right\}$ & $28 \cdot 53$ & $2 \cdot 103$ & $0 \cdot 10-0 \cdot 20$ \\
\hline Gubic & $\left\{\begin{array}{l}\text { Joint regression } \\
\text { Het. between inbreds and } \mathrm{F}_{1} \\
\text { Het. between inbred genotypes } \\
\text { Het. between } \mathrm{F}_{1} \text { genotypes } \\
\text { Het. within inbred genotypes } \\
\text { Het. within } \mathrm{F}_{1} \text { genotypes }\end{array}\right.$ & \begin{tabular}{c|} 
I \\
I \\
4 \\
I \\
9 \\
IO
\end{tabular} & $\left.\begin{array}{r}7 \cdot 63 \\
29 \cdot 82 \\
\mathrm{I} 7 \cdot 69 \\
3 \cdot 04 \\
6 \mathrm{I} \cdot 02 \\
6 \cdot 78\end{array}\right\}$ & $28 \cdot 82$ & & \\
\hline $\begin{array}{l}\text { Mean } \\
\text { chiasmata }\end{array}$ & $\left\{\begin{array}{l}\text { Between inbreds and } F_{1} \\
\text { Between inbred genotypes } \\
\text { Between } \mathrm{F}_{1} \text { inbreds } \\
\text { Within inbred genotypes } \\
\text { Within } \mathrm{F}_{1} \text { genotypes }\end{array}\right.$ & \begin{tabular}{|c|} 
\\
4 \\
I \\
9 \\
IO
\end{tabular} & \begin{tabular}{|}
$30,556 \cdot 73$ \\
I $58 \cdot 14$ \\
$28 \cdot 52$ \\
$93 \cdot 07$ \\
$65 \cdot 75$
\end{tabular} & I I $7 \cdot 25$ & & \\
\hline
\end{tabular}

different. They are larger between inbred than $F_{1}$ plants. This variation within inbred families also, of course, confirms the earlier conclusion of the developmental instability of the homozygotes as compared with the heterozygotes.

Having established a definite distribution pattern for chiasma frequency within anthers it is worthwhile now inquiring, as far as possible, how, during development, it originates. In Allium Darlington and Haque (1955) have demonstrated that localised abnormal chromosome behaviour, including failure of metaphase pairing, is associated with abnormal dyschronisation in the division of p.m.c. In view of this it was worthwhile inquiring whether "normal" differences in the tinning of cell divisions can be correlated with the developmental variation in chiasma frequency. In the next section therefore, data are considered with regard to the timing of cell divisions in the four sections of the anther. 


\section{THE TIMING OF MEIOSIS}

To begin with the problem was to determine whether or not divisions in the four sections were synchronised. Data for this purpose were available for six anthers of a $P_{12}$ plant $\left(P_{1} 2^{4}\right)$ scored in 1954 . The p.m.c. of each section were classified according to their stage of

TABLE 3

The distribution of meiotic stages in anther sections of $\mathrm{P}_{12}{ }^{4}$

\begin{tabular}{|c|c|c|c|c|c|}
\hline \multirow{2}{*}{ Anther } & \multirow{2}{*}{ Section } & \multicolumn{3}{|c|}{ No. of p.m.c. } & \multirow{2}{*}{$\begin{array}{c}\text { " M.I." } \\
\text { (in angles }\end{array}$} \\
\hline & & $\begin{array}{l}\text { At stages } \\
\text { earlier than } \\
\text { metaphase }\end{array}$ & At metaphase & $\begin{array}{l}\text { Later than } \\
\text { metaphase }\end{array}$ & \\
\hline I & $\begin{array}{l}\text { I } \\
2 \\
3 \\
4\end{array}$ & $\begin{array}{l}\mathrm{O} \\
\mathrm{O} \\
\mathrm{O} \\
\mathrm{I}\end{array}$ & $\begin{array}{r}35 \\
7 \\
14 \\
57\end{array}$ & $\begin{array}{l}19 \\
48 \\
42 \\
12\end{array}$ & $\begin{array}{l}56 \\
76 \\
7^{\circ} \\
50\end{array}$ \\
\hline 2 & $\begin{array}{l}1 \\
2 \\
3 \\
4\end{array}$ & $\begin{array}{l}0 \\
0 \\
0 \\
7\end{array}$ & $\begin{array}{l}50 \\
28 \\
50 \\
42\end{array}$ & $\begin{array}{r}9 \\
4^{8} \\
4 \\
2\end{array}$ & $\begin{array}{l}50 \\
65 \\
47 \\
4^{2}\end{array}$ \\
\hline 3 & $\begin{array}{l}1 \\
2 \\
3 \\
4\end{array}$ & $\begin{array}{r}1 \\
0 \\
10 \\
19\end{array}$ & $\begin{array}{l}4^{8} \\
54 \\
56 \\
49\end{array}$ & $\begin{array}{r}1 \\
10 \\
0 \\
0\end{array}$ & $\begin{array}{l}45 \\
50 \\
41 \\
37\end{array}$ \\
\hline 4 & $\begin{array}{l}1 \\
2 \\
3 \\
4\end{array}$ & $\begin{array}{r}\text { I } \\
0 \\
6 \\
33\end{array}$ & $\begin{array}{l}74 \\
74 \\
64 \\
20\end{array}$ & $\begin{array}{l}0 \\
1 \\
0 \\
0\end{array}$ & $\begin{array}{l}45 \\
46 \\
43 \\
26\end{array}$ \\
\hline 5 & $\begin{array}{l}1 \\
2 \\
3 \\
4\end{array}$ & $\begin{array}{r}0 \\
0 \\
3 \\
19\end{array}$ & $\begin{array}{l}30 \\
34 \\
28 \\
20\end{array}$ & $\begin{array}{l}\mathrm{o} \\
\mathrm{o} \\
\mathrm{o} \\
\mathrm{o}\end{array}$ & $\begin{array}{l}44 \\
44 \\
42 \\
31\end{array}$ \\
\hline 6 & $\begin{array}{l}1 \\
2 \\
3 \\
4\end{array}$ & $\begin{array}{l}0 \\
0 \\
0 \\
3\end{array}$ & $\begin{array}{l}20 \\
11 \\
25 \\
24\end{array}$ & $\begin{array}{l}26 \\
37 \\
31 \\
30\end{array}$ & $\begin{array}{l}63 \\
71 \\
61 \\
60\end{array}$ \\
\hline
\end{tabular}

meiosis. The results for three classes of cells, (I) those at first metaphase, (2) at stages earlier and (3) at stages later than first metaphase are given in table 3 .

Chiasma frequencies also were scored in these anthers and are given in table 4 .

For analysis of the timing data a time scale, the metaphase index (M.I.), was calculated as follows :-

$$
\frac{\mathrm{IOO}-a+b}{2}
$$

where $a$ is the percentage of cells at stages earlier than first metaphase and $b$ is the percentage of cells at stages later than first metaphase. 
Because they are based on percentages the M.I. estimates were subsequently transformed to angular values for statistical analysis, and these angular values are also presented in table 3. Sections with low

TABLE 4

Chiasma frequencies per section in anthers of $\mathrm{P}_{1} 2^{4}$.

Ten cells were scored in each section

\begin{tabular}{|c|c|c|c|c|c|}
\hline \multirow{2}{*}{ Anther } & \multicolumn{4}{|c|}{ Section } & \multirow{2}{*}{$\begin{array}{c}\text { Total } \\
\text { chiasmata }\end{array}$} \\
\hline & I & 2 & 3 & 4 & \\
\hline I & I 2 I & I I 5 & IIO & II 6 & \multirow{7}{*}{$\begin{array}{l}462 \\
461 \\
464 \\
473 \\
4^{667} \\
4^{6} \mathrm{I}\end{array}$} \\
\hline 2 & I 13 & I I 5 & 120 & II 5 & \\
\hline 3 & I I 5 & I 16 & 117 & I 16 & \\
\hline 4 & 122 & I 2 I & I 13 & I I 7 & \\
\hline 5 & I I9 & I I 5 & I 13 & 120 & \\
\hline 6 & I I 8 & 118 & 109 & I 16 & \\
\hline Total & 708 & 700 & 682 & 700 & \\
\hline
\end{tabular}

M.I.s, where cells at first metaphase will be amongst the first to reach that stage, will be less advanced in division than those with high M.I.s, where most cells will have already progressed beyond metaphase. It

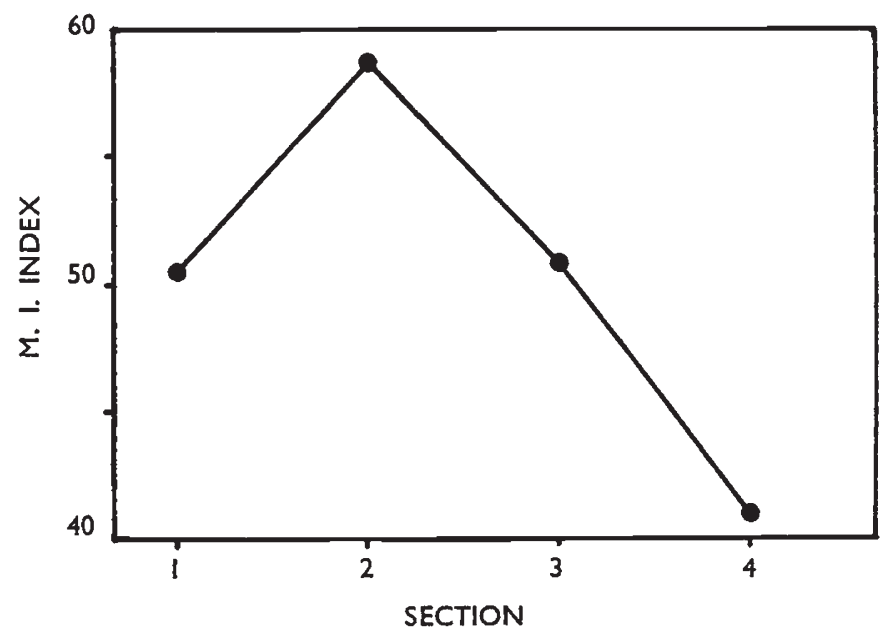

Fig. 2.-The M.I. distribution in anther sections of $P_{12}{ }^{4}$ (see text).

must, of course, be borne in mind that a difference in M.I. does not necessarily imply that p.m.c. proceed through prophase to metaphase at different rates; rather that they may do so at different times.

By means of this arbitrary time scale we can now inquire in some detail into the sequence of meiotic divisions in different regions of the 
anther. It will be immediately apparent from the table that timing is variable between sections. It will be seen furthermore that the variation in timing is consistent between anthers; 2 is the most advanced, 4 the least and I and 3 are intermediate. The general pattern is illustrated in fig. 2.

\section{TABLE 5}

Polynomial regression analysis-M.I. against anther sections

\begin{tabular}{|c|c|c|c|c|}
\hline Item & $\mathrm{N}$ & MS & VR & $P$ \\
\hline Between anthers in mean M.I. & 5 & 479.54 & & \\
\hline Linear $\left\{\begin{array}{l}\text { Joint regression } \\
\text { Het. between anthers }\end{array}\right.$ & $\begin{array}{l}\text { I } \\
5\end{array}$ & $\begin{array}{r}399 \cdot 68 \\
10 \cdot 77\end{array}$ & $37 \cdot 1 \mathrm{I}$ & 0.01 \\
\hline Quadratic $\left\{\begin{array}{l}\text { Joint regression } \\
\text { Het. between anthers }\end{array}\right.$ & $\begin{array}{l}\text { I } \\
5\end{array}$ & $\begin{array}{r}477^{\circ} .04 \\
34^{\circ} .94\end{array}$ & $13 \cdot 65$ & $0.05^{-0.01}$ \\
\hline$\left\{\begin{array}{l}\text { Joint regression } \\
\text { Het. between anthers }\end{array}\right.$ & $\begin{array}{l}\text { I } \\
5\end{array}$ & $\begin{array}{l}63 \cdot 08 \\
22 \cdot 37\end{array}$ & $2 \cdot 82$ & \\
\hline
\end{tabular}

A statistical analysis, by means of polynomial regressions as for chiasma frequency, shows that the linear and quadratic components are significant whereas the cubic regression mean square is not (table 5). The analysis confirms the relation between the timing of meiosis in p.m.c. and their distribution. It shows too that while the basal region is in general more advanced than the tip the timing gradient is not a simple, that is a linear, function of distance-as indeed the graph indicates.

One notes in relation to the above that the vascular system of the anther (fig. 3) is such that the probable order of supply of nutrients and other substances to the sections is $2, \mathrm{I}$ and 3,4-the order of increasing distance from the point of entry of the vascular bundle. It is not unreasonable to suppose therefore that stimulation causing the onset of meiosis, being in the same section order, is provided by a substance diffusing inwards along the vascular strand. Such a substance would not necessarily act immediately but perhaps, through the medium of the cytoplasm, over a period of one or more cell generations.

It has now been established that both in the timing of their meiosis and in the frequency of chiasmata which they form during meiosis the p.m.c. vary in quite well defined developmental patterns within the anthers. In the following section we shall consider whether there is evidence for a causal relation between the two. 


\section{TIMING AND CHIASMA FREQUENCY}

The average chiasma frequency distribution in $P_{\mathrm{I} 2^{4}}$ (see fig. 4 ) is in good agreement with the $195^{8}$ data for inbred lines generally and for

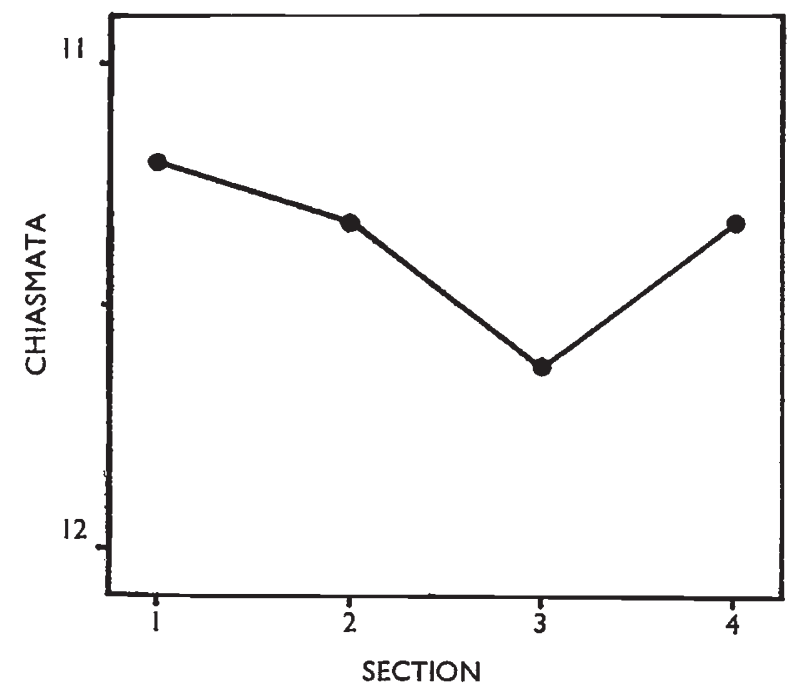

FIG. 4.-Chiasma frequencies per cell in sections of $P_{12}{ }^{4}$ anthers.

$P_{12}$ in $195^{8}$ especially. We note in particular the corresponding low values in section 3 .

The relation between chiasma frequencies and M.I. in $P_{12} 2^{4}$ has been investigated at two levels, the anther and the sections. The results were as follows.
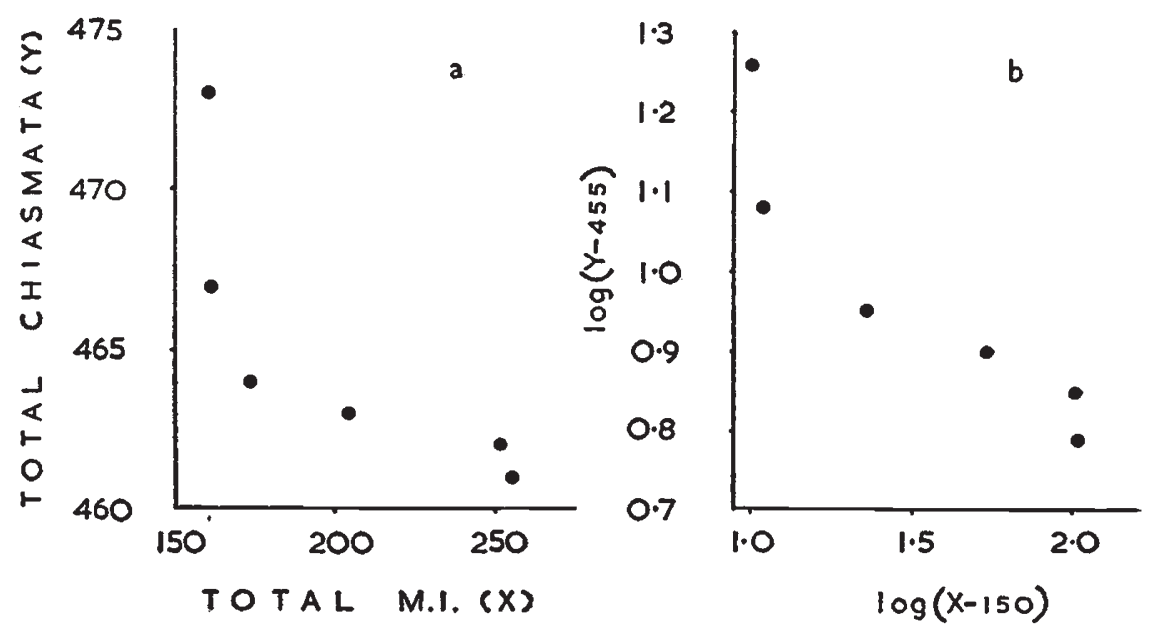

FIG. 5. - Chiasma frequencies plotted against M.I.s of anthers of $P_{12}{ }^{4}$.

Anthers. In graph $5^{a}$ the total chiasmata scored in each $P_{12}{ }^{4}$ anther is plotted against the total M.I. of each. Transformation of the data with the aid of logs straightens this curve $\left(5^{b}\right)$ and permits a 
simple test of significance by means of a linear regression analysis of variance. The regression is significant at the o-or level. Metaphases in the more advanced anthers, it is concluded, have lower chiasma frequencies than in the less advanced. Put in another way, the chiasma frequencies are higher in p.m.c. which come into metaphase first.

The correlation between timing and chiasma frequency is, of course, exactly what would be expected on the basis of the precocity theory, (Darlington, I940). While compatible with this theory the evidence however is not entirely conclusive because, as mentioned earlier, it is not known whether the chromosomes in p.m.c. at metaphase at different times proceed through meiosis, particularly chromosome pairing, at different rates.

TABLE 6

Analysis of variance of mean chiasma frequencies in $\operatorname{PI}_{1}{ }^{4}$ (see text).

\begin{tabular}{|c|c|c|c|}
\hline Item & SS & N & MS \\
\hline Between anthers . & $24 \cdot 50$ & 5 & 4.9 \\
Between sections . & $60 \cdot 50$ & 3 & $20 \cdot 16$ \\
Residual . & $167 \cdot 50$ & 15 & I I.16 \\
Total & $252 \cdot 50$ & 23 & \\
\hline
\end{tabular}

Sections. If p.m.c. dividing early have higher chiasma frequencies than those dividing later it might be expected that sections with low M.I.s, with the first crop of p.m.c. at metaphase, would have higher chiasma frequencies than those with high M.I.s.- where p.m.c. at metaphase would represent the late dividing cells in that region. While such a relation is not ruled out it is clear from a comparison of graphs 3 and 4 that the chiasma frequency variation between sections within an anther is by no means directly or completely dependent on timing. In these graphs it will be seen that the high and low $P_{12}{ }^{4}$ chiasma frequencies do not correspond with the low and high M.I.s for sections. Another cause of chiasma frequency variation between sections is indicated.

A clue to one additional factor controlling the chiasma frequency variation between sections is provided by a straightforward analysis of variance of the chiasma frequencies in $P_{12}{ }^{4}$ (table 6). It will be seen that the mean square for variation between sections is $4 \cdot$ I times greater than the mean square for variation between anthers. While not significant at the 5 per cent. level $(P=0 \cdot \mathrm{I}-0 \cdot 05)$ the much smaller variation between anthers, as compared with that within, suggests a limit to the number of chiasmata per anther and, further, the possibility of competition for chiasmata between sections. Competition for chiasmata within cells is, of course, well established by earlier work (e.g. Mather, I936). 
Evidence confirming and at the same time indicating the nature of the competition between sections is provided by further comparisons between timing and chiasma frequency within anther sections. In fig. 6 section chiasma frequencies are plotted against section M.I.s for
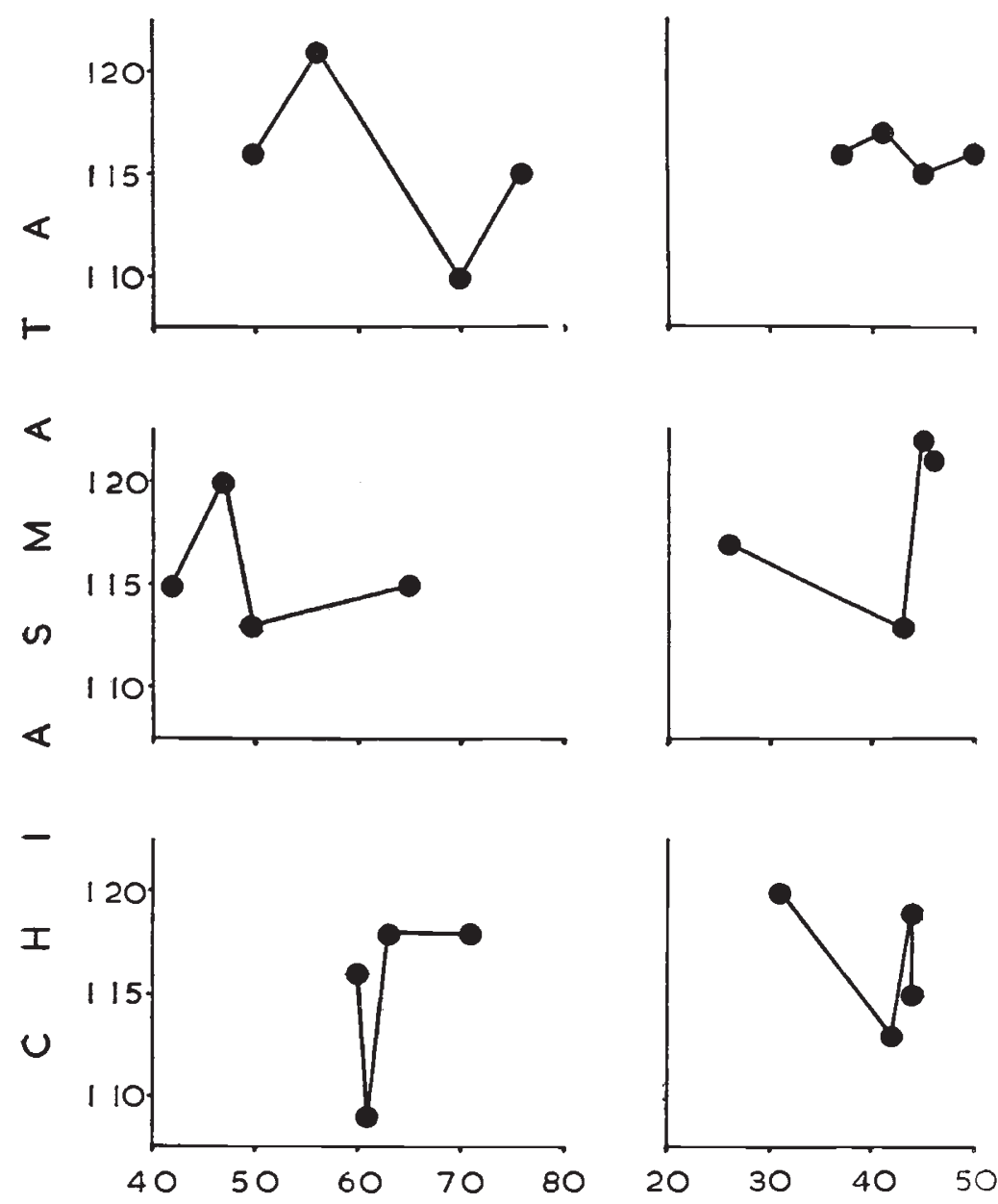

$$
\text { "M.1". }
$$

FIG. 6.-Section chiasma frequencies plotted against section M.I.s in six anthers of $P_{12}{ }^{4}$. Note alternation of chiasma frequencies in relation to timing.

each anther separately. It will be observed that the chiasmata/M.I. curves are characteristically "zig-zag". The chiasma frequencies alternate or, rather, are compensating between successive sections. The compensation it will be observed relates to the distribution of sections with respect to their timing succession, not directly to their spatial distribution. Thus when the chiasma frequencies of the first two sections to divide are high and low respectively that of the third 
will bc high, the fourth low; or alternatively the sequence may be low, high, low, high.

It will be recalled that substances were inferred to diffuse into the anther in order of sections 2, I and 3, 4. Given that a substance limiting chiasma frequency and itself of limited amount is supplied to sections in this order the compensation effect can be explained where excessive absorption by one region curtails the supply to the next and vice versa. Whether timing and chiasma frequency are influenced by the same substance or by different substances acting independently cannot be established by the present data.

\section{SUMMARY AND CONCLUSIONS}

Differences in chromosome behaviour between cells are shown to be a useful index of the developmental variation occurring within a tissue. For two characters investigated in rye p.m.c., namely chiasma frequency and the timing sequence of meiotic divisions, well defined patterns of variation are demonstrated within anthers. Variation in both characters is probably influenced by the system of distribution of nutrient or other substances to the anther during its development.

The pattern of developmental variation in chiasma frequency is more consistent in anthers of heterozygous than homozygous plants.

Timing and chiasma frequency are related; p.m.c. reaching metaphase early have higher chiasma frequencies than those at metaphase later.

Another factor affecting chiasma frequency variation within an anther is competition for chiasmata between different regions.

Acknowledgments. - We are indebted to Professor K. Mather, for his advice, to Mr J. B. Thompson for the use of some of his data and to Mr R. Morley-Jones for advice on statistical matters.

\section{REFERENCES}

DARlington, C. D. 1940. The prime variables of meiosis. Biol Rev., 15, 307-322. DARLington, C. D. AND HAQUe, A. I955. The timing of mitosis and meiosis in Allium Ascalonicum: a problem of differentiation. Heredity, 9, I 17 -1 27.

HERTWIG, G. 1935. Die Vielwertigkeit der Speicheldrusenkerne und chromosomen bie Drosophila melanogaster. Z.I.A.V., 70, 496-501.

MATHER, K. 1936. Competition between bivalents during chiasma formation. P.R.S., B, $120,208-227$.

REES, H. AND THOMPSON, J. B. 1956. Genotypic control of chromosome behaviour in rye III. Chiasma frequency in homozygotes and heterozygotes. Heredity, IO, 409-424.

REES, H. 1955. Genotypic control of chromosome behaviour in rye. I. Inbred Lines. Heredity, 9, 93-1 6 . 